Article

\title{
Iron-incorporated nitrogen-doped carbon materials as oxygen reduction electrocatalysts for zinc-air batteries
}

\author{
Kai Chen a,b, Suqin Ci a,*, Qiuhua Xu a, Pingwei Cai b, Meizhen $\mathrm{Li}^{\text {a, }}$ Lijuan Xiang a, Xi Hu a, \\ Zhenhai Wen ${ }^{b, \#}$ \\ a Key Laboratory of Jiangxi Province for Persistent Pollutants Control and Resources Recycle, Nanchang Hangkong University, Nanchang 330063, Jiangxi, \\ China \\ b CAS Key Laboratory of Design and Assembly of Functional Nanostructures, and Fujian Key Laboratory of Nanomaterials, Fujian Institute of Research on \\ the Structure of Matter, Chinese Academy of Sciences, Fuzhou 350002, Fujian, China
}

\section{A R T I C L E I N F O}

\section{Article history:}

Received 12 October 2019

Accepted 10 November 2019

Published 5 May 2020

\section{Keywords:}

Oxygen reduction reaction

Electrocatalyst

Fe-N-C activity sites

Alkaline/neutral medium

Zn-air battery

\begin{abstract}
A B S T R A C T
The application of electrocatalysts for the oxygen reduction reaction (ORR) is vital in a variety of energy conversion technologies. Exploring low-cost ORR catalysts with high activity and long-term stability is highly desirable, although it still remains challenging. Herein, we report a facile and reliable route to convert ZIF-8 modified by Fe-phenanthroline into Fe-incorporated and N-doped carbon dodecahedron nanoarchitecture (Fe-NCDNA), in which carbon nanosheets are formed in situ as the building blocks with uniform Fe-N-C species decoration. Systematic electrochemical studies demonstrate that the as-synthesized Fe-NCDNA electrocatalyst possesses highly attractive catalytic features toward the ORR in terms of activity and durability in both alkaline and neutral media. The $\mathrm{Zn}$-air battery with the optimal Fe-NCDNA catalyst as the cathode performs impressively, delivering a power density of $184 \mathrm{~mW} \mathrm{~cm}^{-2}$ and a specific capacity of $801 \mathrm{mAh} \mathrm{g}^{-1}$; thus, it exhibits great competitive advantages over those of the $\mathrm{Zn}$-air devices employing a Pt-based cathode electrocatalyst.
\end{abstract}

(C) 2020, Dalian Institute of Chemical Physics, Chinese Academy of Sciences. Published by Elsevier B.V. All rights reserved.

\section{Introduction}

The pressing crises of environmental pollution and fossil fuel energy depletion have propelled humans to explore feasible, reliable, and renewable energy technology solutions [1]. Various fuel cells including the Zn-air battery and $\mathrm{H}_{2}-\mathrm{O}_{2}$ fuel cells are capable of directly converting chemical energy into electrical energy, and with the absence of heat engine processes and the Carnot cycle, these fuel cells show high energy conversion efficiencies [2,3]. Recently, the demand for environmentally friendly batteries with high specific energy and excel- lent reliability has stimulated the investigation of $\mathrm{Zn}$-air batteries, of which the $\mathrm{Zn}$ anode is highly recognized for its high capacity, high safety, and low cost. Nonetheless, many conundrums remain unsolved, e.g., sluggish oxygen reduction reactions (ORRs) on the cathode side [4,5]. The ORR, as the most important cathode reaction in the $\mathrm{Zn}$-air battery, is generally recognized to have a significant impact on the performance of associated devices [6-8]. Although Pt-based catalysts have been regarded as the most efficient cathode catalysts, their prohibitive cost greatly limits their widespread commercial application. Therefore, it is of great importance to develop

\footnotetext{
* Corresponding author. E-mail: sqci@nchu.edu.cn

\# Corresponding author. Tel: +86-591-63173534; E-mail: wen@fjirsm.ac.cn

The work was supported by the National Natural Science foundation of China $(21566025,21875253)$, the Science Fund of Jiangxi Province for Distinguished Young Scholars (20162BCB23044), and the Jiangxi Provincial Graduate Innovation Special Fund Project (YC2018-S362). DOI: S1872-2067(19)63507-2 | http://www.sciencedirect.com/science/journal/18722067 | Chin. J. Catal., Vol. 41, No. 5, May 2020
} 
high-performance non-precious metal ORR electrocatalysts $[9,10]$.

In recent years, transition metal carbon nitrides (M-N-C, M = $\mathrm{Co}, \mathrm{Fe}$, et al.) have emerged as one of the most promising alternative electrocatalysts to Pt-based materials toward the ORR. In these alternative electrocatalysts, the $\mathrm{M}-\mathrm{N}_{x}$ moiety normally functions as the major active site $[11,12]$, and its activity is dependent on the density of the active sites, surface area, and porous structure $[13,14]$. Such M-N-C catalysts can be directly synthesized by the pyrolysis of precursors containing transition metal, $\mathrm{N}$, and $\mathrm{C}$ species; metal atoms tend to aggregate into large particles due to their high surface energy, and their porous structures cannot be effectively controlled [15-17], which leads to relatively poor catalytic activity. Currently, MOF-derived catalysts have attracted significant research interest due to their potential applications in various fields of energy conversion and storage [18-22]. This has motivated us to explore an efficient method to prepare ideal electrocatalysts with favorable properties, including abundant $\mathrm{N}$ species, high surface areas, and adjustable pore sizes for the ORR [5,23].

Herein, we report a facile and reliable route for the controllable synthesis of Fe-incorporated and N-doped carbon dodecahedron nanoarchitectures (Fe-NCDNA), which were exploited as electrocatalysts for the ORR and were applied as cathode electrocatalysts in a Zn-air battery. Both results consistently confirmed the highly attractive catalytic properties of Fe-NCDNA with activity comparable to those of Pt-based materials as well as excellent durability.

\section{Experimental}

\subsection{Chemicals and materials}

Zinc nitrate hexahydrate $\left(\mathrm{Zn}\left(\mathrm{NO}_{3}\right)_{2} \cdot 6 \mathrm{H}_{2} \mathrm{O}\right)$, 2-methylimidazole $\left(\mathrm{C}_{4} \mathrm{H}_{6} \mathrm{~N}_{2}\right)$, ferrous sulfate heptahydrate $\left(\mathrm{FeSO}_{4} \cdot 7 \mathrm{H}_{2} \mathrm{O}\right)$, absolute methanol $\left(\mathrm{CH}_{3} \mathrm{OH}\right)$, and absolute ethanol $\left(\mathrm{C}_{2} \mathrm{H}_{5} \mathrm{OH}\right)$ were purchased from Sinopharm Chemical Reagent Co., Ltd. Nafion solution (5\%) and 1,10-phenanthroline $\left(\mathrm{C}_{12} \mathrm{H}_{8} \mathrm{~N}_{2}\right)$ were purchased from Aladdin Reagent (Shanghai) Co., Ltd. All the reagents were used directly without further purification.

\subsection{Synthesis of the catalysts}

\subsubsection{Synthesis of ZIF-8 [24,25]}

Typically, $\mathrm{Zn}\left(\mathrm{NO}_{3}\right)_{2} \cdot 6 \mathrm{H}_{2} \mathrm{O}$ (2.000 g) and 2-methylimidazole $(1.813 \mathrm{~g})$ were dissolved in 45 and $30 \mathrm{~mL}$ of methanol, respectively. Subsequently, a 2-methylimidazole solution was injected in a $\mathrm{Zn}\left(\mathrm{NO}_{3}\right)_{2} \cdot 6 \mathrm{H}_{2} \mathrm{O}$ solution under vigorously stirring for $16 \mathrm{~h}$ at room temperature. The precipitates were centrifuged and washed with methanol and deionized water several times, followed by drying in a vacuum oven at $60^{\circ} \mathrm{C}$ overnight.

\subsubsection{Synthesis of Fe-NCDNA-X $(X=0,1,2,3)$ and $N C$}

The powders of ZIF-8 (0.300 g) and 1,10-phenanthroline ( $0.136 \mathrm{~g}$ ) were added to $20 \mathrm{~mL}$ of methanol and sonicated for $30 \mathrm{~min}$ at room temperature. Thereafter, $20-\mathrm{mL}$ aliquots of methanol solutions containing $0.012,0.015$, and $0.200 \mathrm{~g}$ of $\mathrm{FeSO}_{4} \cdot 7 \mathrm{H}_{2} \mathrm{O}$ were separately injected. After vigorously stirring for $2 \mathrm{~h}$ at room temperature, the mixture was evaporated to dryness at $80^{\circ} \mathrm{C}$. Finally, the Fe-NCDNA- $X(X=1,2,3)$ samples were obtained by calcination at $900{ }^{\circ} \mathrm{C}$ for $2 \mathrm{~h}$ at a heating rate of $5^{\circ} \mathrm{C} \mathrm{min}-1$ under Ar atmosphere. Under the same conditions, Fe-NCDNA-0 was synthesized without adding $\mathrm{FeSO}_{4} \cdot 7 \mathrm{H}_{2} \mathrm{O}$. NC was prepared by the pyrolysis of ZIF-8 under the same annealing condition.

\subsection{Physical characterizations}

X-ray powder diffraction (XRD) patterns were recorded on an X-ray diffractometer (Miniflex6000, Rigaku) at $40 \mathrm{kV}$ and 15 $\mathrm{mA}$ using $\mathrm{Cu} K_{\alpha}$ radiation $(\lambda=1.54178 \AA$ ). The specific surface area and pore size distributions of the samples were analyzed by the Brunauer-Emmett-Teller (BET) method using $\mathrm{N}_{2}$ adsorption-desorption isotherms on a Micromeritics Instrument Corporation sorption analyzer (Micromeritics TriStar II 3020). The Raman spectra of the catalysts were recorded on a LabRAM HR over a range of $300-3000 \mathrm{~cm}^{-1}$. The Fe concentrations of the catalysts were determined by inductively coupled plasma atomic emission spectroscopy (ICP-MS). The morphologies of the catalysts were determined using Hitachi SU8010 at a high vacuum pressure and an accelerating voltage of $5 \mathrm{kV}$. A scanning electron microscope (SEM, KYKY-EM3900M) and a transmission electron microscope (TEM, JEM-2010F) were used to observe the morphology and nanostructure of the materials. X-ray photoelectron spectroscopy (XPS) measurements were carried out on an ESCALAB 250Xi XPS system using a monochromatic $\mathrm{Al} \mathrm{K \alpha}$ source and a charge neutralizer.

\subsection{Electrochemical characterization}

\subsubsection{Electrochemical measurements}

The electrochemical measurements were conducted in a three-electrode system on a CHI760 electrochemical station (CH instrument Co.) at room temperature $\left(25^{\circ} \mathrm{C}\right.$ ). A carbon electrode served as the counter electrode. Meanwhile, a $\mathrm{Hg} / \mathrm{HgO}$ in $1 \mathrm{M} \mathrm{KOH}$ solution served as the reference electrode in alkaline medium, and an $\mathrm{Ag} / \mathrm{AgCl}$ electrode in saturated $\mathrm{KCl}$ served as the reference electrode in neutral and acidic media. A rotating disk electrode (RDE) with a glassy carbon (GC) disk of $3 \mathrm{~mm}$ in diameter and a rotating ring-disk electrode (RRDE) with a GC disk (4.0 mm diameter) and a Pt ring (5.0 mm inner diameter and $7.0 \mathrm{~mm}$ outer diameter) served as the substrate for the working electrode. Experimentally, $5.0 \mathrm{mg}$ of the sample (containing $20 \mathrm{wt} \% \mathrm{Pt} / \mathrm{C}$ ) was ultrasonically dispersed in $1 \mathrm{~mL}$ of the solution containing $50 \mu \mathrm{L}$ of Nafion solution, $200 \mu \mathrm{L}$ of ethanol, and $750 \mu \mathrm{L}$ of water for $30 \mathrm{~min}$ to form homogeneous catalyst ink. The volumes of the catalyst ink were $6 \mu \mathrm{L}$ and 10 $\mu \mathrm{L}$ for the RDE and RRDE tests, respectively. The $\mathrm{O}_{2}$-saturated $0.1 \mathrm{M} \mathrm{KOH}, 0.1 \mathrm{M}$ phosphate buffer solution (PBS, $\mathrm{pH}=7$ ), and $0.5 \mathrm{M} \mathrm{H}_{2} \mathrm{SO}_{4}$ were used as alkaline, neutral, and acidic media, respectively. For the $\mathrm{CV}$ measurements, the scan rate was 50 $\mathrm{mV} \mathrm{s}^{-1}$, while for the RDE/RRDE test, it was $5 \mathrm{mV} \mathrm{s}^{-1}$. 


\subsubsection{Data analysis}

All the potentials in this work were converted to the reversible hydrogen electrode (RHE) potential, and the potential conversion formula is as follows: $E_{\mathrm{RHE}}=E_{\mathrm{Hg} / \mathrm{HgO}}+0.059 \mathrm{~V} \times \mathrm{pH}$ (alkaline medium) and $E_{\mathrm{RHE}}=E_{\mathrm{Ag} / \mathrm{AgCl}}+0.059 \mathrm{~V} \times \mathrm{pH}$ (neutral/acidic medium).

The electron transfer number $(n)$ was obtained by the Koutecky-Levich (K-L) Eq. (1):

$$
\frac{1}{J}=\frac{1}{J_{L}}+\frac{1}{J_{K}}=\frac{1}{B W^{1 / 2}}+\frac{1}{J_{K}},
$$

where $J$ is the measured current density; $J_{\mathrm{K}}$ and $J_{\mathrm{L}}$ are the kinetic and limiting current densities, respectively; $w$ is the linear rotation speed ( $\mathrm{rpm} \mathrm{s}^{-1}$ ) of the disk.

For the RRDE measurements, the polarization curves were recorded at a disk rotation rate of $1600 \mathrm{rpm}$. The potential of the ring was set at $1.4 \mathrm{~V}$ (vs. RHE). The $\mathrm{H}_{2} \mathrm{O}_{2}$ yield and the electron transfer number $(n)$ were calculated by Eqs. (2) and (3), respectively, as follows:

$$
\begin{gathered}
\mathrm{H}_{2} \mathrm{O}_{2} \%=200 \times \frac{I_{r} / N}{I_{d}+I_{r} / N^{\prime}}, \\
\mathrm{n}=4 \times \frac{I_{d}}{I_{d}+I_{r} / N^{\prime}},
\end{gathered}
$$

where $I_{\mathrm{d}}$ is the disk current, $I_{\mathrm{r}}$ is the ring current, and $N(0.442)$ is the ring collection efficiency.

\subsection{Configuration and measurement of Zn-air battery}

Ten milligrams of the sample was ultrasonically dispersed in $1 \mathrm{~mL}$ of the solution containing $100 \mu \mathrm{L}$ of Nafion solution, $450 \mu \mathrm{L}$ of ethanol, and $450 \mu \mathrm{L}$ of water for $30 \mathrm{~min}$ to form homogeneous catalyst ink. The volume of catalyst ink coated onto carbon paper $\left(1 \mathrm{~cm}^{2}\right)$ was $100 \mu \mathrm{L}$, after which the coated carbon paper was dried with a lamp. A Zn plate served as the anode electrode and a $6 \mathrm{M} \mathrm{KOH}$ solution was adopted as the electrolyte. The open-circuit voltage (VOC) and galvanostatic discharge data were collected in the LAND testing system. The specific capacitor of the assembled battery was calculated from Eq. (4):

$$
C_{s p}=\frac{i \times t}{\Delta m}
$$

where $i, t$, and $\Delta m$ represent the discharge current, discharge time, and the weight of consumed $\mathrm{Zn}$, respectively.
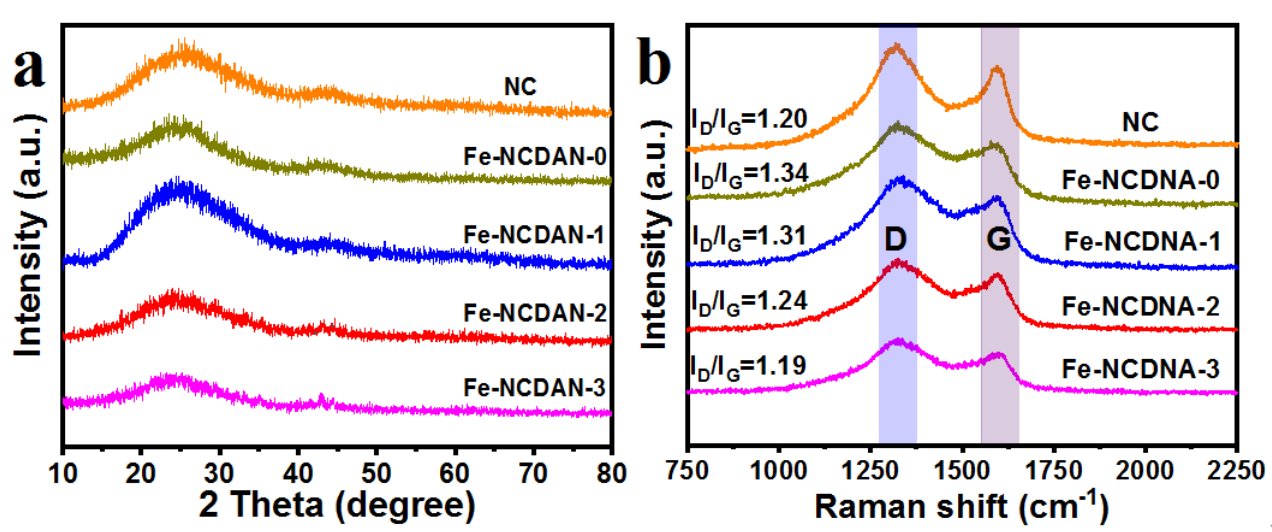

Fig. 2. XRD patterns (a) and Raman spectra (b) of NC, Fe-NCDNA-0, Fe-NCDNA-1, Fe-NCDNA-2, and Fe-NCDNA-3.

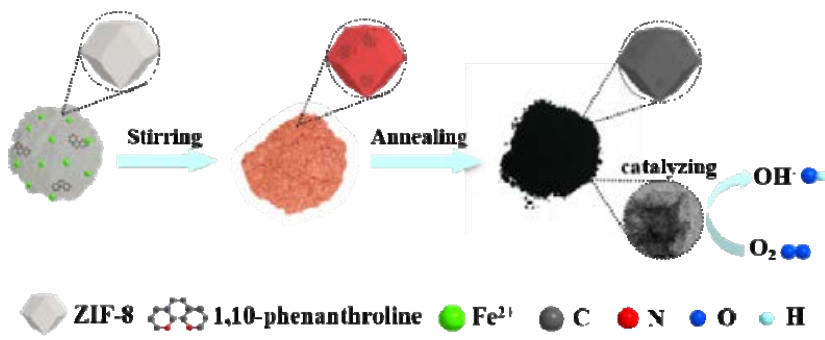

Fig. 1. Schematic illustration of the catalyst synthesis process.

\section{Results and discussion}

It is a classic reaction, 1,10-phenanthroline and $\mathrm{Fe}^{2+}$ form a red-brown Fe-phenanthroline (Fe-phen) product [26,27]. And N-rich carbon can be obtained by the direct pyrolysis of ZIF-8. Therefore, the catalysts containing $\mathrm{Fe}$ and $\mathrm{N}$ were prepared through the carbonization of ZIF-8 with absorbed Fe-phen. During the carbonization process, the $\mathrm{N}$ group combined with the Fe species to form $\mathrm{FeN}_{x}$ structure units, which were confined to the porous carbon structure derived from ZIF-8. Fig. 1 schematically illustrates the synthetic process for preparing Fe-NCDNA. The entire synthesis process was implemented by the initial in situ growth of Fe-phen complexes on the surface of ZIF-8 through a reaction between $\mathrm{Fe}^{2+}$ and 1,10-phenanthroline, noting that 1,10-phenanthroline can be favorably adsorbed on ZIF-8 through $\pi-\pi$ interactions $[28,29]$, which leads to a uniform coating of Fe-phen complexes on ZIF-8. A set of Fe-NCDNA catalysts can be obtained by pyrolyzing the composites of Fe-phen-coated ZIF-8 (ZIF-8@Fe-phen).

According to the XRD pattern (Fig. S1(a)), the as-prepared ZIF-8 catalyst shows diffraction peaks in accordance with the previous result [25], indicating the successful synthesis of ZIF-8. Simultaneously, the prepared ZIF-8 and ZIF-8@Fe-phen are determined by SEM observation to be regular dodecahedrons (Fig. S2). After a high-temperature pyrolysis reaction, ZIF-8 and ZIF-8@Fe-phen were converted to N-rich carbon and $\mathrm{Fe}$, and $\mathrm{N}$ co-doped carbon, respectively. The XRD patterns (Fig. 2(a)) of NC and Fe-NCDNA-0 display two broad peaks near $26^{\circ}$ and $44^{\circ}$, which are assigned to the (002) and (101) crystal planes of graphitic carbon $[30,31]$. Although the peaks of Fe, 
$\mathrm{FeC}_{x}$, and $\mathrm{FeN}_{x}$, located around $44^{\circ}$, are observed for the Fe-NCDNA-3, Fe-NCDNA-2, and Fe-NCDNA-1 materials, respectively, these peaks are not sharp. This may be due to the low loading and the presence of amorphous Fe [32]. ICP-MS results confirm that the final Fe contents are $2.61 \mathrm{wt} \%, 3.30 \mathrm{wt} \%$, and 4.34 wt $\%$ for Fe-NCDNA-1, Fe-NCDNA-2, and Fe-NCDNA-3 catalysts, respectively.

To further unveil the texture of carbon, the Raman spectra of the catalysts were recorded. Fig. 2(b) presents two distinct peaks in the range of $1250-1750 \mathrm{~cm}^{-1}$ corresponding to the D (around $1320 \mathrm{~cm}^{-1}$ ) and $\mathrm{G}$ bands (around $1610 \mathrm{~cm}^{-1}$ ). Mostly, the D-band is attributed to the defect sites or grain boundaries, while the G-band corresponds to the band stretching of $s p^{2}$ bonded pairs $[33,34]$, such as $\mathrm{C}=\mathrm{C}, \mathrm{C}=\mathrm{O}$, and $\mathrm{N}=\mathrm{C}$. After normalization, the area ratio of the D-band and G-band $\left(I_{\mathrm{D}} / I_{\mathrm{G}}\right)$ can indicate the defect induced by $\mathrm{N}$-doping. Evidently, the $I_{\mathrm{D}} / I_{\mathrm{G}}$ values for NC and Fe-NCDNA-0 are 1.20 and 1.34, respectively, which illustrates that the introduced phenanthroline induced the formation of defects during the pyrolysis process. Conversely, the $I_{\mathrm{D}} / I_{\mathrm{G}}$ value decreases gradually as the Fe content increases, and the value drops from 1.34 to 1.19; this suggests a decrease in the number of defects and an improved degree of graphitization. Since Fe is an excellent catalyst to induce graphitization [33], the inductive effect increases with the Fe content; thus, the $I_{\mathrm{D}} / I_{\mathrm{G}}$ value decreases.

The $\mathrm{N}_{2}$ adsorption-desorption test was conducted to evaluate the porosity and structural features. Fig. S1(b) depicts the corresponding $\mathrm{N}_{2}$ adsorption-desorption isotherm of ZIF-8, which is a type-I curve. Similarly, it addresses the microporous characteristics (inset in Fig. S1(b)) and typical reversible adsorption. Contrarily, all the catalysts deliver a large specific surface area. As shown in Fig. S3(a), there is a distinct hysteresis loop at $P / P_{0}$ of $0.4 \sim 1.0$, which is a distinctive feature of mesoporous materials. Nevertheless, at a low relative pressure $\left(P / P_{0}<0.40\right)$, the adsorption quantity declines sharply, indicating the existence of micropores in all the materials. Meanwhile, we calculate the BET surface area of the samples. The BET surface area of Fe-NCDNA-0 is calculated to be $1240 \mathrm{~m}^{2}$ $\mathrm{g}^{-1}$, which is higher than those of $\mathrm{NC}\left(1124 \mathrm{~m}^{2} \mathrm{~g}^{-1}\right)$, Fe-NCDNA-1 (809 $\mathrm{m}^{2} \mathrm{~g}^{-1}$ ), Fe-NCDNA-2 (897 $\mathrm{m}^{2} \mathrm{~g}^{-1}$ ), and Fe-NCDNA-3 (649 $\left.\mathrm{m}^{2} \mathrm{~g}^{-1}\right)$. A downtrend is observed with the specific surface area when Fe doping is included, and it could be the result of Fe occupying the microporous structure $[4,23]$. In addition, Fe-NCDNA-2 has the highest specific surface area among the Fe-doped samples and retains the most abundant pore size distribution compared to those of all the other catalysts (Fig. S3(b)). Combined with the results of the electrochemical test, such a hierarchical pore structure could supply more sites and enhance the accessibility of oxygen and electrolyte [35].

SEM was employed to investigate the morphology of the samples. Fig. S2 shows that the synthetic ZIF-8 is a regular dodecahedron, which is in agreement with previous reports. From the SEM images in Fig. 3, it is clear that all the catalysts retain the similar morphology derived from ZIF-8. Meanwhile, the morphologies of the catalysts changed in varying degrees due to the adjustment of the Fe content. Among them,

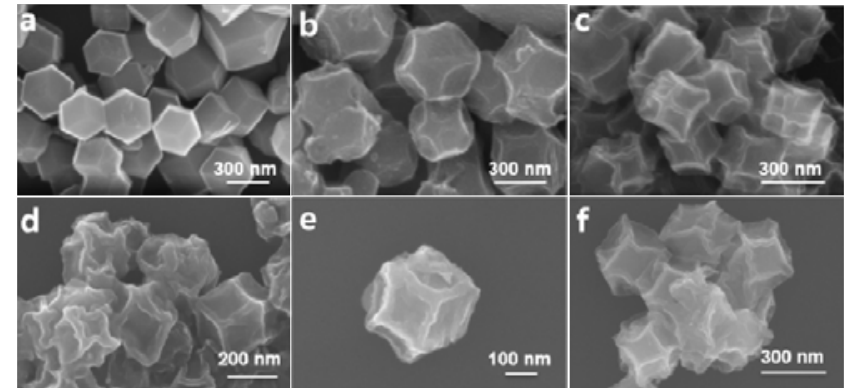

Fig. 3. SEM images of $\mathrm{NC}$ (a), Fe-NCDNA-0 (b), Fe-NCDNA-1 (c), Fe-NCDNA-2 (d,e), and Fe-NCDNA-3 (f).

Fe-NCDNA-2 revealed remarkable distortion and a rough surface. Therefore, according to the $\mathrm{N}_{2}$ adsorption-desorption test and SEM images, the the amount of Fe not only affect the surface area and pore size distribution but also the morphology.

Furthermore, TEM was adopted to gain insight into the construction of the as-prepared Fe-NCDNA-2 catalyst. Figs. 4(a), 4(b), and Figs. S4(a), S4(b) show that Fe-NCDNA-2 has a carbon nanocage structure with in situ-formed carbon nanosheets. However, the nanoparticles commonly found in Fe, N co-doped carbon materials were not be observed. Meanwhile, the high-resolution TEM (HRTEM) image did not manifest lattice fringes and diffraction rings due to the low content of Fe and the existence of amorphous carbon (Fig. 4(c)) [32,36,37]. As displayed in the high-annular dark-field scanning TEM (HAADF-STEM) images (Fig. 4(d)) and corresponding elemental mapping images of the resultant Fe-NCDNA-2 catalyst, a uniform distribution of trace Fe (yellow), $\mathrm{N}$ (green), and carbon elements (red) exists in the carbon frameworks.

XPS analysis was performed to identify the elemental composition and surface chemical binding states of the samples. The results clearly reveal that the doping of $\mathrm{Fe}$ and $\mathrm{N}$ atoms in

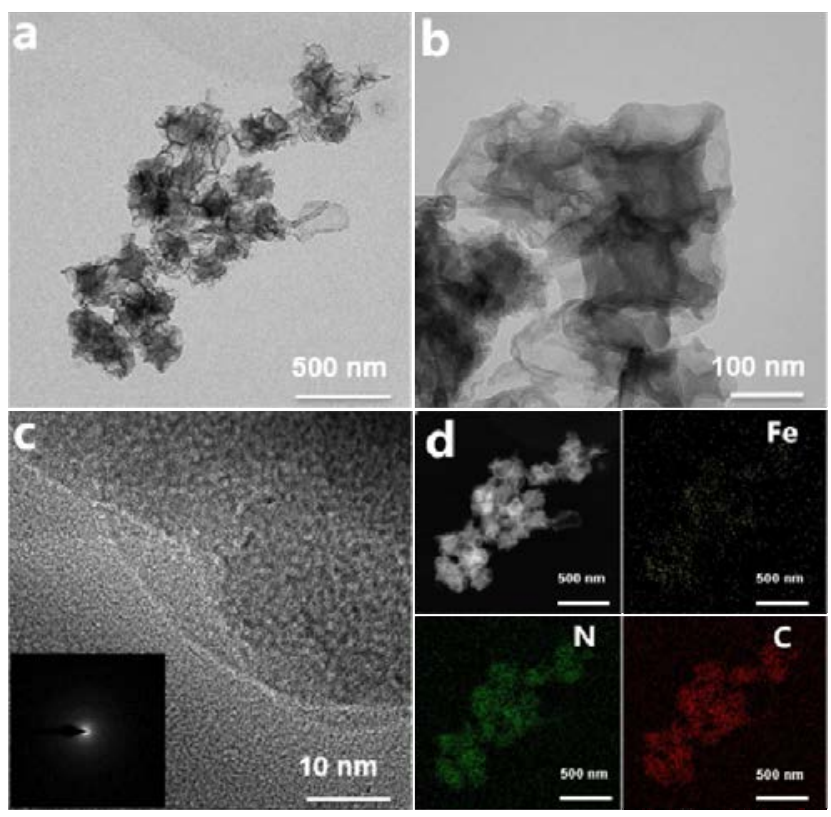

Fig. 4. (a,b) TEM images of Fe-NCDNA-2. (c,d) HRTEM image, HAADF-STEM image, and corresponding mapping images of Fe-NCDNA-2. 


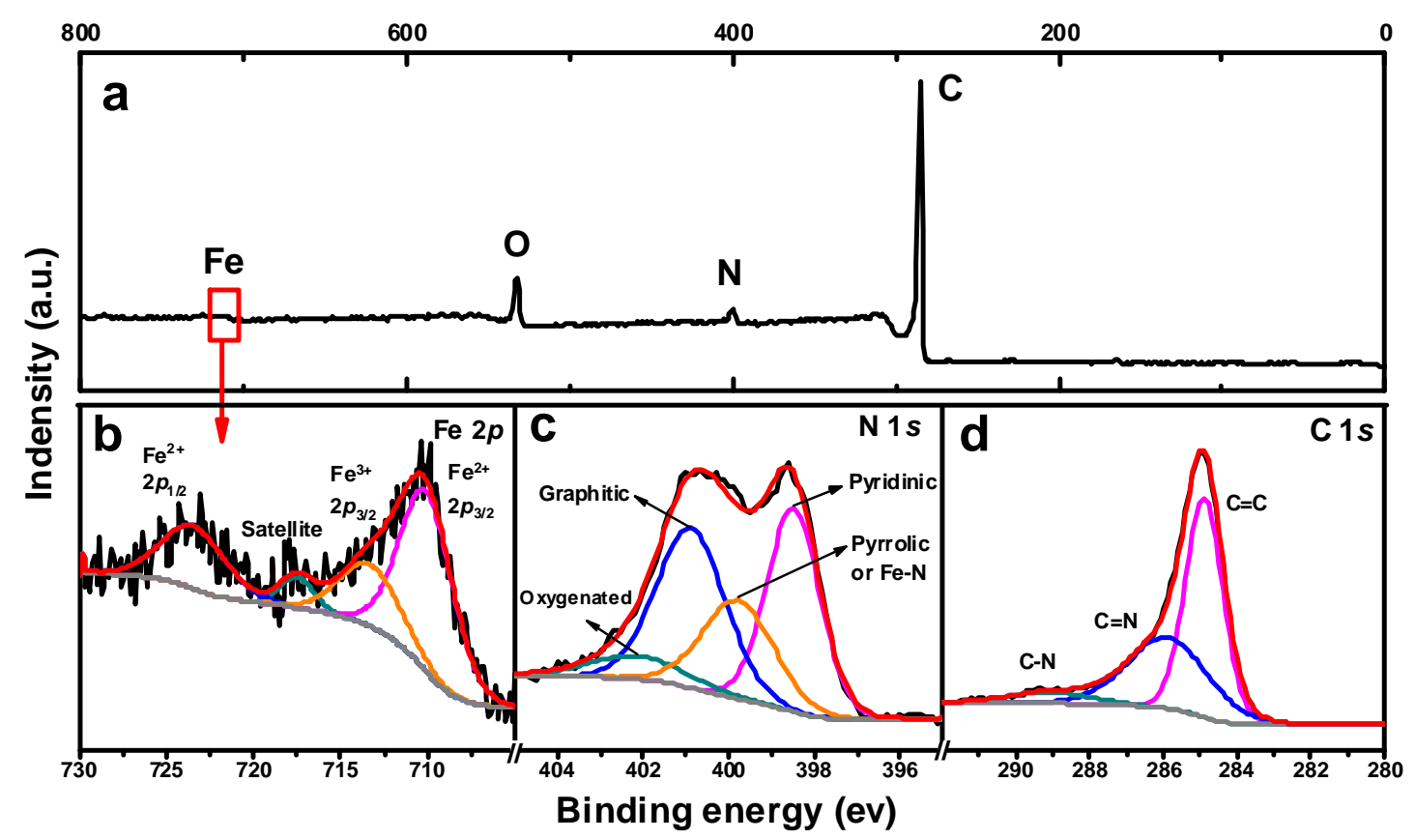

Fig. 5. (a) XPS survey of Fe-NCDNA-2. Corresponding high-resolution XPS spectra of Fe $2 p$ (b), N $1 s$ (c), and C $1 s$ (d).

the carbon matrix was successful (Fig. 5(a)). The C $1 s$ high-resolution spectra (Fig. 5(d)) show that there are two distinct peaks (located at 284.8 and $285.7 \mathrm{eV}$ ) and a broad shoulder peak $(288.3 \mathrm{eV})$, which are assigned to $\mathrm{C}=\mathrm{C}, \mathrm{C}=\mathrm{N}$, and $\mathrm{C}-\mathrm{N}$, respectively [23]. Furthermore, $\mathrm{C}=\mathrm{C}$ accounts for more than half of the content; $\mathrm{C}=\mathrm{N}$ comes second, and $\mathrm{C}-\mathrm{N}$ has the least content (Fig. S5(b), Table S1). The $\mathrm{N} 1 s$ high-resolution spectra (Fig. 5(c)) can be subdivided into four different groups: pyridinic $\mathrm{N}(398.5 \mathrm{eV}, 34.77 \%)$, pyrrolic $\mathrm{N}$ or Fe-N (399.8 eV, $22.54 \%$ ) [38-41], graphitic $\mathrm{N}$ (400.8 eV, 35.50\%), and oxygenated $\mathrm{N}(402.3 \mathrm{eV}, 7.19 \%)$ [42-44]. According to previous literatures $[45,46]$, pyridinic $\mathrm{N}$ is the main catalytic active site for the ORR in $\mathrm{N}$-doped carbon, and the graphitic $\mathrm{N}$ improves the limiting current density. In addition, the content of pyridine $\mathrm{N}$ is much higher than that of pyrrolic $\mathrm{N}$ (or Fe-N), and the content of graphitic $\mathrm{N}$ increases gradually when additional $\mathrm{N}$ and Fe are introduced (Fig. S5(a), Table S1). Fig. 3(b) manifests the Fe (Fe $2 p$ ) survey spectrum. Based on the reports [47-49], the two distinct peaks at 710.2 and $713.8 \mathrm{eV}$ are attributed to the binding energies of the $2 p_{3 / 2}$ orbitals of the $\mathrm{Fe}^{2+}$ and $\mathrm{Fe}^{3+}$ species, respectively. For the $2 p_{1 / 2}$ orbitals, the peak at $723.3 \mathrm{eV}$ is assigned to the binding energy of $\mathrm{Fe}^{2+}$. This suggests the existence of $\mathrm{FeN}_{x}$ and $\mathrm{FeC}_{x}$ species in Fe-NCDNA-2 [25,50,51]. Moreover, a satellite peak is observed at $719.5 \mathrm{eV}$.

The ORR activity of the electrocatalysts was firstly assessed by cyclic voltammetry (CV) in an Ar or $\mathrm{O}_{2}$ saturated $0.1 \mathrm{M} \mathrm{KOH}$ solution at a scan rate of $50 \mathrm{mV} \mathrm{s}^{-1}$. As shown in Figs. S6a and S6b, Fe-NCDNA-2 displays a noticeable oxygen reduction peak at $0.857 \mathrm{~V} v s$. RHE, which is superior to those of Fe-NCDNA-1 (0.853 V), Fe-NCDNA-3 (0.835 V), Fe-NCDNA-0 (0.821 V), as well as $20 \mathrm{wt} \% \mathrm{Pt} / \mathrm{C}(0.817 \mathrm{~V})$. As a reference, the $\mathrm{NC}$ catalyst exhibits a poor oxygen reduction peak of $0.796 \mathrm{~V}$, indicating the vital role of $\mathrm{Fe}$ and $\mathrm{N}$ atoms in improving the ORR performance.
To further evaluate the ORR performance, a linear sweep voltammetry (LSV) test with RDE was executed, and the results were compared to those of the commercial $20 \mathrm{wt} \% \mathrm{Pt} / \mathrm{C}$ catalyst (Fig. 6(a)). According to the plots, Fe-NCDNA-2 delivers the best ORR activity as it has the most positive half-wave potential $\left(E_{1 / 2}=0.863 \mathrm{~V}\right)$ compared to those of Fe-NCDNA-1 (0.846 V), Fe-NCDNA-3 (0.840 V), Fe-NCDNA-0 (0.860 V), NC (0.807 V), and $\mathrm{Pt} / \mathrm{C}(0.841 \mathrm{~V})$. By comprehensive characterization and electrochemical results, it is apparent that $\mathrm{N}$ doping can improve the ORR activity. Moreover, the high-efficiency catalytic unit was formed to further enhance the catalytic activity due to the incorporation of Fe. Meanwhile, we noticed that the Fe content affected the structure of the sample, and Fe-NCDNA-2 could reveal more active sites [52], making its ORR performance the most outstanding. Subsequently, the Tafel slopes of the samples were obtained by analyzing the corresponding RDE polarization curves (Fig. S6(c)). Among them, Fe-NCDNA-2 presented the smallest slope of $80 \mathrm{mV} \mathrm{dec}^{-1}$ compared to those of Fe-NCDNA-1, Fe-NCDNA-3, Fe-NCDNA-0, NC, and commercial Pt/C. This demonstrates that Fe-NCDNA-2 has a relatively high catalytic current and further corroborates its outstanding ORR activity [53]. For a better understanding of the electrochemical processes, RDE measurements were employed at different rotating rates, and the corresponding kinetic parameters of Fe-NCDNA-2 were calculated using the $\mathrm{K}-\mathrm{L}$ equation (Figs. 6(b), 6(c)). The computed value is 3.87, which is close to the theoretical value of 4.0 for the ORR. This indicates the efficient reduction of oxygen over the electrocatalyst via a four-electron reduction pathway. Based on the RRDE data, the yield of peroxide species $\left(\mathrm{HO}_{2}^{-}\right)$and the transferred number of electrons can be determined (Fig. S6(d)). Similarly, the transferred number of electrons is consistent with the calculated value from the $\mathrm{K}-\mathrm{L}$ plots. Moreover, the $\mathrm{HO}_{2}^{-}$yield over 

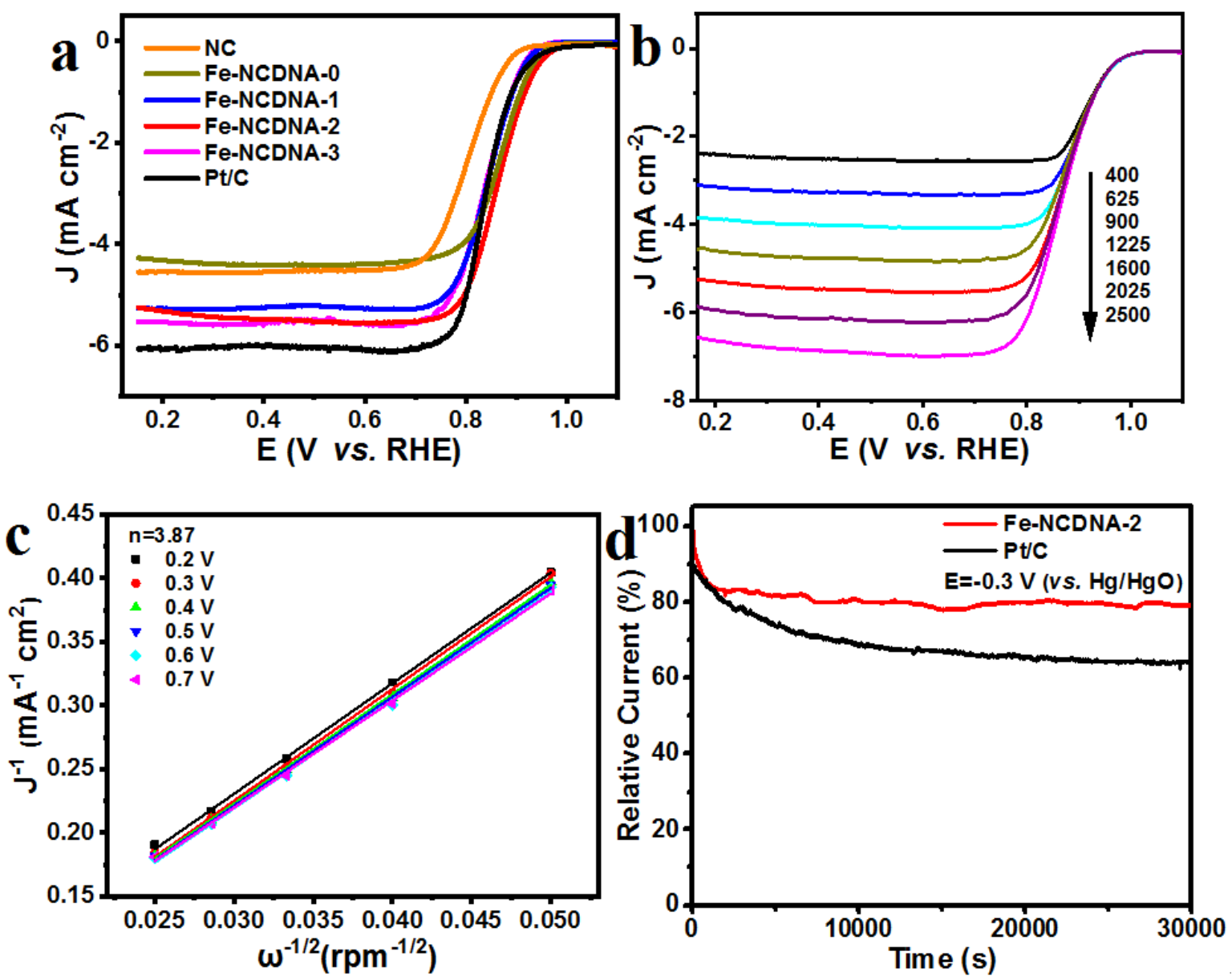

Fig. 6. ORR electrocatalytic performances in $\mathrm{O}_{2}$-saturated $0.1 \mathrm{M} \mathrm{KOH}$. (a) LSV curves at a scan rate of $5 \mathrm{mV} \mathrm{s} \mathrm{s}^{-1}$ at $1600 \mathrm{rpm}$; (b) Polarization curves of Fe-NCDNA-2 at different rotating rates; (c) K-L plots of Fe-NCDNA-2 at different potentials; (d) Chronoamperometric curves of Fe-NCDNA-2 and Pt/C for a $30000 \mathrm{~s}$ run.

Fe-NCDNA-2 is less than $6 \%$ compared to $29.6 \%$ over the commercial Pt/C in the range of 0.2-0.9 V. This implies that the material has a relatively high four-electron pathway selectivity and avoids the two-electron pathway to peroxide. Chronoamperometric tests (Fig. 6(d)) show that Fe-NCDNA-2 exhibits better long-term stability (80\%) than $\mathrm{Pt} / \mathrm{C}$ (64\%), i.e., retention of the initial current, after a $30000 \mathrm{~s}$ run in a $0.1 \mathrm{M} \mathrm{KOH}$ solution. Methanol tolerance test was employed to assess the poison tolerance of the catalyst. Fig. S7(a) shows that the curves almost coincide, while there is significant oxidation peak in Fig. S7(b), revealing that the Fe-NCDNA-2 catalyst exhibits excellent poison tolerance compared to that of $\mathrm{Pt} / \mathrm{C}$.

When in a neutral medium, a set of Fe-NCDNA catalysts also exhibits catalytic properties toward the ORR. For the CV tests (Figs. S8(a), S8(b)), Fe-NCDNA-2 displays an oxygen reduction peak at $0.689 \mathrm{~V}$, which is more positive than that of Pt/C. Similar to the case in alkaline medium, the $E_{1 / 2}$ value of Fe-NCDNA-2 is $0.715 \mathrm{~V}$, suggesting a positive potential compared to those of Fe-NCDNA-1 (0.692 V), Fe-NCDNA-3 (0.628 V), Fe-NCDNA-0 (0.631 V), NC (0.497 V), and Pt/C (0.673 V) (Fig. 7(a)). In addition, the Tafel slopes of the catalysts were obtained from analyzing the corresponding LSV data in RDE at 1600 rpm. Fig. S8(c) demonstrates that Fe-NCDNA-2 has the lowest slope of $105 \mathrm{mV} \mathrm{dec}-1$. RDE measurements at different rotating rates (Fig. 7 (b)) and RRDE measurement at $1600 \mathrm{rpm}$ (Fig. S8(d)) were also conducted to evaluate the electrochemical behavior. From the results, the $\mathrm{H}_{2} \mathrm{O}^{-}$yield over Fe-NCDNA-2 is less than $8 \%$ over the range of $0.1-0.8 \mathrm{~V}$, revealing that the evolution of $\mathrm{H}_{2} \mathrm{O}^{-}$is dramatically suppressed on the Fe-NCDNA-2 electrocatalyst. Further, the transferred number of electrons determined from the K-L plots (Fig. 7(c)) matches the calculated value obtained by RRDE measurement (close theoretical value of 4.0). This illustrates that the ORR processes over the Fe-NCDNA-2 catalyst occur preferably via a four-electron reduction pathway. As depicted in Fig. 7(d), Fe-NCDNA-2 and Pt/C have similar long-term stabilities with $77 \%$ and $76 \%$ retention of the initial current, respectively, after catalyzing for $30000 \mathrm{~s}$ in $0.1 \mathrm{M}$ PBS solutions. Table 1 lists the electrocatalytic ORR performance parameters of the prepared materials and depicts the great competitiveness over the Pt/C and some Pt-free catalysts in both alkaline and neutral media. [41,54-58] In addition, Fe-NCDNA-2 has an $E_{1 / 2}$ value of 0.745 $\mathrm{V}$ in the $\mathrm{O}_{2}$-saturated $0.5 \mathrm{M} \mathrm{H}_{2} \mathrm{SO}_{4}$ solution, which is negative compared with $0.783 \mathrm{~V}$ for Pt/C (Fig. S9(a)). Systematic electrochemical studies demonstrate that Fe-NCDNA-2 follows a four-electron reduction pathway and has a high long-term sta- 

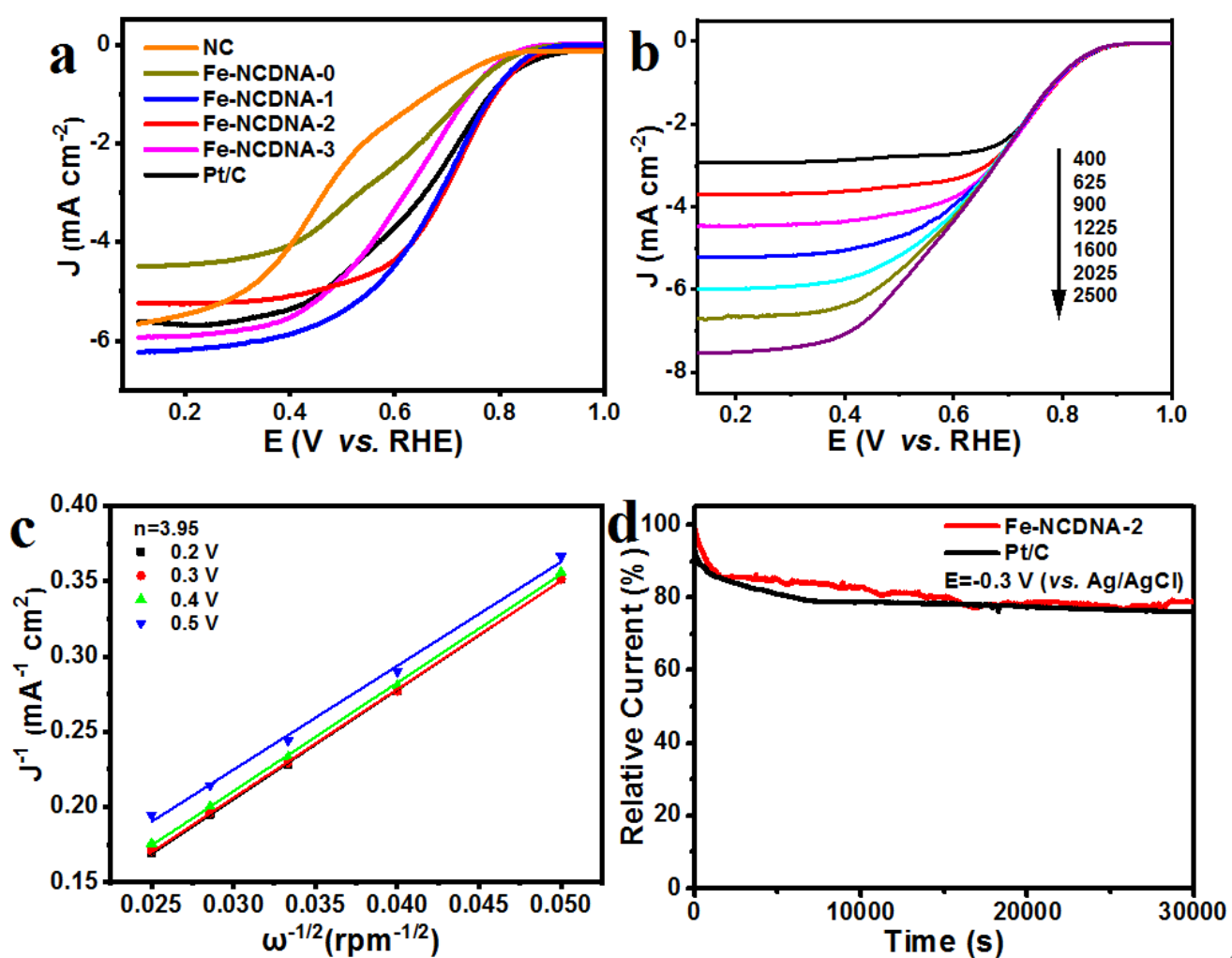

Fig. 7. ORR electrocatalytic performances in $\mathrm{O}_{2}$-saturated $0.1 \mathrm{M}$ PBS. (a) LSV curves at a scan rate of $5 \mathrm{mV} \mathrm{s}^{-1}$ at $1600 \mathrm{rpm}$; (b) Polarization curves of Fe-NCDNA-2 at different rotating rates; (c) K-L plots of Fe-NCDNA-2 at different potentials; (d) Chronoamperometric curves of Fe-NCDNA-2 and Pt/C for the 30000 s run.

bility (Figs. S9(b)-9(d) and Fig. S10).

A home-made Zn-air battery was constructed to further demonstrate the practical application of Fe-NCDNA-2 as an ORR electrocatalyst. The Zn-air battery was constructed using the Fe-NCDNA-2 catalyst loaded on carbon paper as the air-cathode and $\mathrm{Zn}$ plate as the anode in a $6 \mathrm{M} \mathrm{KOH}$ electrolyte (Fig. 8(a)). For comparison, the $20 \mathrm{wt} \% \mathrm{Pt} / \mathrm{C}$ catalyst loaded on carbon paper was used as the air-cathode and was also measured under the same condition. The $V_{0 c}$ of the batteries were recorded for $12 \mathrm{~h}$ to verify that their voltages are close and that the assembled Zn-air batteries have low self-discharge (Fig. 8(b)). The battery employing the Fe-NCDNA-2 catalyst exhibited a $V_{\mathrm{OC}}$ of $1.46 \mathrm{~V}$; this value is slightly higher than that of $\mathrm{Pt} / \mathrm{C}$ $(1.43 \mathrm{~V})$. The power density is not only one of the important indicators for evaluating battery performance, but also reflects the catalytic activity of the material. It is worth noting that the maximum power density for the $\mathrm{Zn}$-air battery employing the
Fe-NCDNA-2 catalyst as the cathode is calculated to be $184 \mathrm{~mW}$ $\mathrm{cm}^{-2}$, which is higher than that of the commercial Pt/C (173 $\mathrm{mW} \mathrm{cm}-2$, Fig. 8(c)). Moreover, from the inset in Fig. 8(c), it is evident that a red LED light $(\sim 2.0 \mathrm{~V})$ is lit by two $\mathrm{Zn}$-air batteries connected in series. During the discharge process at a current density $10 \mathrm{~mA} \mathrm{~cm}-2$, the batteries with the Fe-NCDNA-2 catalyst presented better performance than that of the commercial $\mathrm{Pt} / \mathrm{C}$, and their voltage plateaued at $1.28 \mathrm{~V}$ with a specific capacity of $801 \mathrm{mAh} \mathrm{g}^{-1}$ when normalized to the weight of the consumed $\mathrm{Zn}$. This value is slightly more positive than that of Pt/C (799 mAh g-1, Fig. 8(d)). The above results are superior to many reported results $[52,53,58-62]$ and further confirm a comparable performance and application of Fe-NCDNA-2 toward the ORR. To acquire the rate discharge performance curves, the batteries employing the optimal Fe-NCDNA and $\mathrm{Pt} / \mathrm{C}$ catalysts as the air cathode were employed for a discharge operation at current densities of $2,4,6,8,10$, and $2 \mathrm{~mA} \mathrm{~cm}^{-2}$

Table 1

Summary of the ORR properties in alkaline and neutral solutions.

\begin{tabular}{|c|c|c|c|c|c|c|}
\hline \multirow{2}{*}{ Sample } & \multicolumn{3}{|c|}{$0.1 \mathrm{M} \mathrm{KOH}$} & \multicolumn{3}{|c|}{$0.1 \mathrm{M}$ PBS } \\
\hline & $E_{\text {onset }} / \mathrm{V}$ vs.RHE & $E_{1 / 2} / \mathrm{V}$ vs.RHE & $\mathrm{J}_{\mathrm{L}} @ 0.5 \mathrm{~V} / \mathrm{mA} \mathrm{cm}^{-2}$ & $E_{\text {onset }} / \mathrm{V}$ vs.RHE & $E_{1 / 2} / \mathrm{V}$ vs.RHE & $\mathrm{J}_{\mathrm{L}} @ 0.2 \mathrm{~V} / \mathrm{mA} \mathrm{cm}^{-2}$ \\
\hline $\mathrm{NC}$ & 0.93 & 0.807 & -4.52 & 0.87 & 0.497 & -5.64 \\
\hline Fe-NCDNA-0 & 0.97 & 0.860 & -4.35 & 0.91 & 0.631 & -4.5 \\
\hline Fe-NCDNA-1 & 0.95 & 0.846 & -5.26 & 0.93 & 0.692 & -6.2 \\
\hline Fe-NCDNA-2 & 0.99 & 0.863 & -5.55 & 0.94 & 0.715 & -5.23 \\
\hline Fe-NCDNA-3 & 0.94 & 0.840 & -5.55 & 0.90 & 0.628 & -5.92 \\
\hline $\mathrm{Pt} / \mathrm{C}$ & 1.00 & 0.841 & -6.09 & 0.96 & 0.673 & -5.6 \\
\hline
\end{tabular}



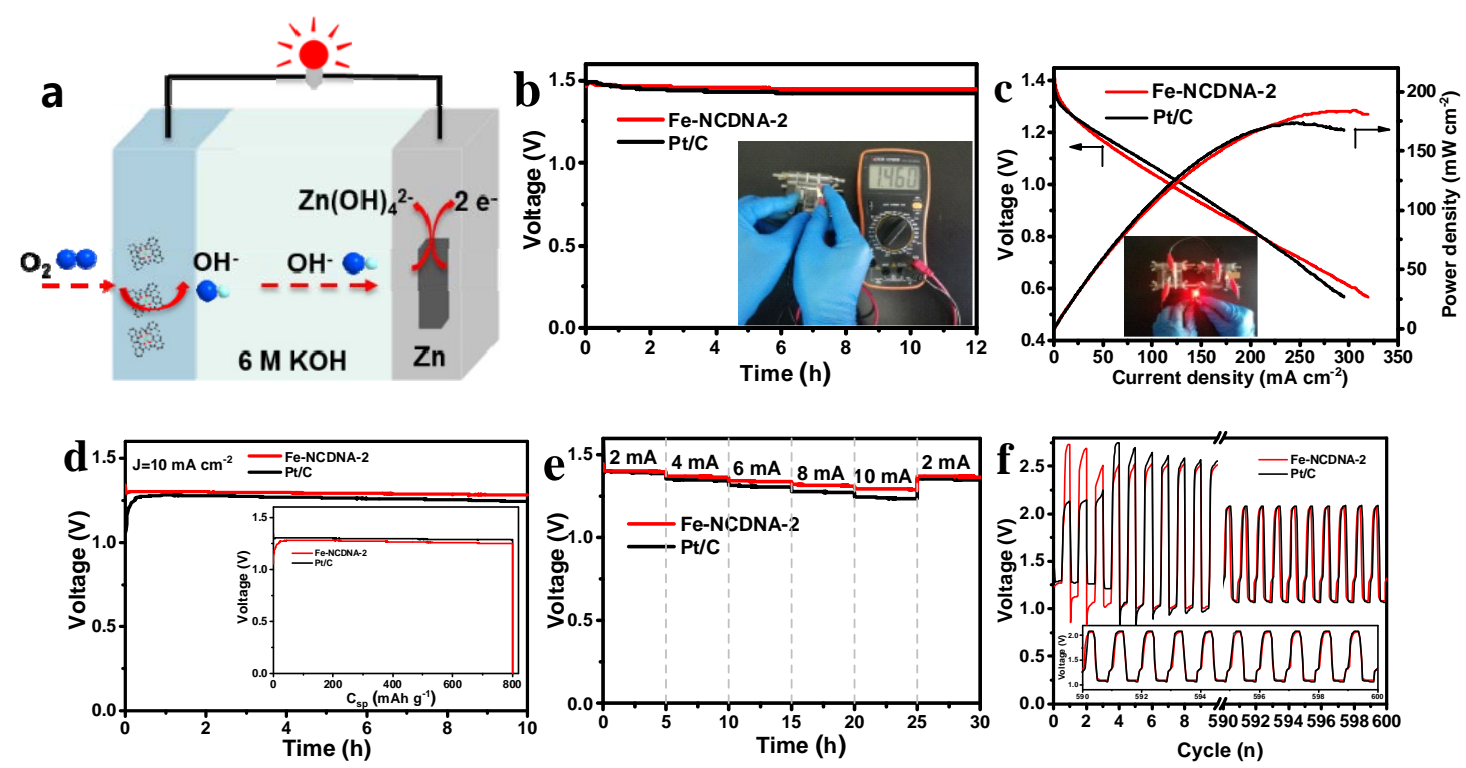

Fig. 8. (a) Schematic of the home-made Zn-air battery employing Fe-NCDNA-2 as the ORR catalyst; (b) Open-circuit voltage curve; (c) Discharge polarization curves and power density. The inset shows the digital graph of a red LED being powered by the constructed Zn-air battery; (d) Galvanostatic discharge curves of the $\mathrm{Zn}$-air batteries with the Fe-NCDNA-2 and Pt/C as catalysts at the current density of $10 \mathrm{~mA} \mathrm{~cm}^{-2}$. (Inset shows the specific capacities of the Zn-air batteries employing Fe-NCDNA-2 and Pt/C, normalized to the weight of the consumed Zn); (e) Galvanostatic discharge of the Zn-air batteries at different current densities; (f) Galvanostatic discharge-charge cycling curves at $10 \mathrm{~mA} \mathrm{~cm}-2$ per cycle for $10 \mathrm{~min}$.

(Fig. 8(e)). The voltage decreased steadily as the discharge current density increased. Furthermore, there was no noticeable voltage drop during $30 \mathrm{~h}$ of operation. As described in Fig. 8(f), the Zn-air battery employing the Fe-NCDNA-2 catalyst exhibits a high cycling stability when repeatedly subjected to discharge and charge processes at $10 \mathrm{~mA} \mathrm{~cm}^{-2}$ for 600 cycles without any distinct augment in the voltage gap of the charge and discharge processes. In addition, the battery with Fe-NCDNA-2 has a smaller voltage polarization, especially after a long cycle, compared to that of the device with Pt/C.

\section{Conclusions}

In summary, we reported a facile route for the controllable synthesis of a catalyst with a carbon dodecahedron nanoarchitecture and formed in situ carbon nanosheets loaded uniformly with Fe-N-C species. Systematic electrochemical tests demonstrated that the Fe-NCDNA-2 electrocatalysts exhibited a more positive half-wave potential, a lower Tafel slope, and better long-term stability than the commercial $\mathrm{Pt} / \mathrm{C}$ in both alkaline and neutral media. The home-made $\mathrm{Zn}$-air batteries employing the optimal Fe-NCDNA catalyst also verified the feasibility of its practical applications as an ORR electrocatalyst. The present work can inspire researchers to explore similar N-doped transition metal porous carbon catalysts for a variety of applications.

\section{References}

[1] D. Larcher, J. M. Tarascon, Nat. Chem., 2015, 7, 19-29.

[2] L. Z. Gu, L. H. Jiang, X. N. Li, J. T. Jin, J. H. Wang, G. Q. Sun, Chin. J. Catal., 2016, 37, 539-548.
[3] W. Shi, Y. C. Wang, C. Chen, X. D. Yang, Z. Y. Zhou, S. G. Sun, Chin. J. Catal., 2016, 37, 1103-1108.

[4] B. Y. Xia, Y. Yan, N. Li, H. B. Wu, X. W. Lou, X. Wang, Nat. Energy, 2016, 1, 15006.

[5] H. H. Jin, H. Zhou, W. Q. Li, Z. H. Wang, J. L. Yang, Y. L. Xiong, D. P. He, L. Chen, S. C. Mu, J. Mater. Chem. A, 2018, 6, 20093-20099.

[6] C. Tang, B. Wang, H. F. Wang, Q. Zhang, Adv. Mater., 2017, 29, 173185.

[7] W. Xia, A. Mahmood, Z. B. Liang, R. Q. Zou, S. J. Guo, Angew. Chem. Int. Edit., 2016, 55, 2650-2676.

[8] Y. G. Li, H. J. Dai, Chem. Soc. Rev., 2014, 43, 5257-5275.

[9] Z. W. Chen, D. Higgins, A. P. Yu, L. Zhang, J. J. Zhang, Energy Environ. Sci., 2011, 4, 3167-3192.

[10] C. Du, X. L. Liu, G. H. Ye, X. H. Gao, Z. H. Zhuang, P. Li, D. Xiang, X. K. Li, A. Z. Clayborne, X. G. Zhou,W. Chen, ChemSusChem, 2019, 12, 1017-1025.

[11] S. H. Liu, J. R. Wu, Electrochim. Acta, 2014, 135, 147-153.

[12] J. T. Ding, P. Wang, S. Ji, H. Wang, V. Linkov, R. F. Wang, Electrochim. Acta, 2019, 296, 653-661.

[13] J. D. Yi, R. Xu, Q. Wu, T. Zhang, K. T. Zang, J. Luo, Y. L. Liang, Y. B. Huang, R. Cao, ACS Energy Lett., 2018, 3, 883-889.

[14] D. Xiang, X. J. Bo, X. H. Gao, C. Du, P. Li, L. D. Zhu,W. Chen, J. Colloid Interface Sci., 2019, 534, 655-664.

[15] A. J. Han, W. X. Chen, S. L. Zhang, M. L. Zhang, Y. H. Han, J. Zhang, S. F. Ji, L. R. Zheng, Y. Wang, L. Gu, C. Chen, Q. Peng, D. S. Wang, Y. D. Li, Adv. Mater., 2018, 30, 1706508.

[16] P. Y. Ren, S. Q. Ci, Y. C. Ding, Z. H. Wen, Appl. Surf. Sci., 2019, 481, 1206-1212.

[17] S. M. Zhang, H. Y. Zhang, W. M. Zhang, X. X. Yuan, S. L. Chen, Z. F. Ma, Chin. J. Catal., 2018, 39, 1427-1435.

[18] S. Bhattacharyya, C. Das, T. K. Maji, RSC Adv., 2018, 8, 26728-26754.

[19] G. Q. Zou, H. S. Hou, P. Ge, Z. D. Huang, G. G. Zhao, D. L. Yin, X. B. Ji, Small, 2018, 14, 1702648. 


\section{Graphical Abstract}

Chin. J. Catal., 2020, 41: 858-867 doi: S1872-2067(19)63507-2

Iron-incorporated nitrogen-doped carbon materials as oxygen reduction electrocatalysts for zinc-air batteries

Kai Chen, Suqin Ci*, Qiuhua Xu, Pingwei Cai, Meizhen Li, Lijuan Xiang, Xi Hu, Zhenhai Wen*

Nanchang Hangkong University; Fujian Institute of Research on the Structure of Matter, Chinese Academy of Sciences

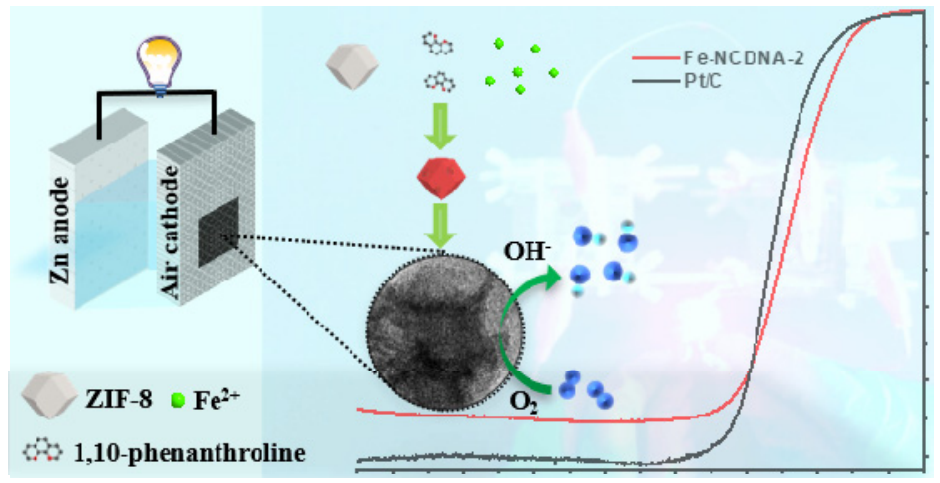

The modified ZIF-8 catalyst is converted to Fe-incorporated N-doped carbon catalyst, showing highly attractive catalytic features toward the ORR in alkaline and neutral media. Meanwhile, the $\mathrm{Zn}$-air battery employing Fe-NCDNA-2 as the cathode displays competitive advantages over the device using a Pt-based electrocatalyst.

[20] B. Y. Guan, X. Y. Yu, H. B. Wu, X. W. Lou, Adv. Mater., 2017, 29, 1703614.

[21] S. Li, G. Zhang, X. Tu, J. Li, ChemElectroChem, 2018, 5, 701-707.

[22] X. B. He, F. X. Yin, H. Wang, B. H. Chen, G. R. Li, Chin. J. Catal., 2018, $39,207-227$.

[23] J. Wang, Z. Q. Huang, W. Liu, C. R. Chang, H. L. Tang, Z. J. Li, W. X. Chen, C. J. Jia, T. Yao, S. Q. Wei, Y. Wu,Y. D. Lie, J. Am. Chem. Soc., 2017, 139, 17281-17284.

[24] X. C. Huang, Y. Y. Lin, J. P. Zhang, X. M. Chen, Angew. Chem. Int. Ed., 2006, 45, 1557-1559.

[25] Y. J. Chen, S. F. Ji, Y. G. Wang, J. C. Dong, W. X. Chen, Z. Li, R. A. Shen, L. R. Zheng, Z. B. Zhuang, D. S. Wang, Y. D. Li, Angew. Chem. Int. Ed., 2017, 56, 6937-6941.

[26] W. W. Brandt, F. P. Dwyer, E. C. Gyarfas, Chem. Rev., 1954, 54, 959-1017.

[27] M. T. Carter, M. Rodriguez, A. J. Bard, J. Am. Chem. Soc., 1989, 111, 8901-8911.

[28] C. Ren, H. Li, R. Li, S. Xu, D. Wei, W. Kang, L. Wang, L. Jia, B. Yang, J. Liu, RSC Adv., 2016, 6, 33302-33307.

[29] F. Y. Yi, D. Chen, M. K. Wu, L. Han, H. L. Jiang, ChemPlusChem, 2016, $81,675-690$.

[30] Q. J. Mo, N. N. Chen, M. D. Deng, L. C. Yang, Q. S. Gao, ACS Appl. Mater. Interfaces, 2017, 9, 37721-37730.

[31] R. Z. Zhang, S. J. He, Y. Z. Lu, W. Chen, J. Mater. Chem. A, 2015, 3, 3559-3567.

[32] Z. Liu, J. Liu, H. B. Wu, G. R. Shen, Z. Y. Le, G. Chen, Y. F. Lu, Nanoscale, 2018, 10, 16996-17001.

[33] A. C. Ferrari, J. C. Meyer, V. Scardaci, C. Casiraghi, M. Lazzeri, F. Mauri, S. Piscanec, D. Jiang, K. S. Novoselov, S. Roth, A. K. Geim, Phys. Rev. Lett., 2006, 97, 187401/1-187401/4.

[34] Y. Wang, H. Y. Liu, K. Wang, S. Q. Song, P. Tsiakaras, Appl. Catal. B, 2017, 210, 57-66.

[35] Q. L. Zhu, W. Xia, L. R. Zheng, R. Q. Zou, Z. Liu,Q. Xu, ACS Energy. Lett., 2017, 2, 504-511.
[36] H. J. Yu, L. Shang, T. Bian, R. Shi, G. I. N. Waterhouse, Y. F. Zhao, C. Zhou, L. Z. Wu, C. H. Tung, T. R. Zhang, Adv. Mater., 2016, 28, 5080-5086.

[37] M. Bron, J. Radnik, M. Fieber-Erdmann, P. Bogdanoff, S. Fiechter, J. Electroanal. Chem., 2002, 535, 113-119.

[38] J.-D. Yi, R. Xu, Q. Wu, T. Zhang, K.-T. Zang, J. Luo, Y.-L. Liang, Y.-B. Huang, R. Cao, ACS Energy Lett., 2018, 3, 883-889.

[39] J. Y. Cheon, T. Kim, Y. Choi, H. Y. Jeong, M. G. Kim, Y. J. Sa, J. Kim, Z. Lee, T.-H. Yang, K. Kwon, Sci. Rep., 2013, 3, 2715.

[40] B. Guo, Q. Ju, R. Ma, Z. Li, Q. Liu, F. Ai, M. Yang, S. Kaskel, J. Luo, T. Zhang, J. Wang, J. Mater. Chem. A, 2019, 7, 19355-19363.

[41] R. Ma, R. Xing, G. Lin, Y. Zhou, Q. Liu, M. Yang, C. Hu, K. Yan, J. Wang, Mater. Chem. Front, 2018, 2, 1489-1497.

[42] D. G. Gu, Y. Zhou, R. G. Ma, F. F. Wang, Q. Liu, J. C. Wang, Nano-Micro Lett., 2018, 10, 29/1-29/12.

[43] G. X. Lin, R. G. Ma, Y. Zhou, C. Hu, M. H. Yang, Q. Liu, S. Kaskel, J. C. Wang, J. Colloid Interface Sci, 2018, 527, 230-240.

[44] G. J. Tao, L. X. Zhang, L. S. Chen, X. Z. Cui, Z. L. Hua, M. Wang, J. C. Wang, Y. Chen, J. L. Shi, Carbon, 2015, 86, 108-117.

[45] H. W. Liang, W. Wei, Z. S. Wu, X. L. Feng, K. Mullen, J. Am. Chem. Soc., 2013, 135, 16002-16005.

[46] G. Wu, C. M. Johnston, N. H. Mack, K. Artyushkova, M. Ferrandon, M. Nelson, J. S. Lezama-Pacheco, S. D. Conradson, K. L. More, D. J. Myers, P. Zelenay, J. Mater. Chem., 2011, 21, 11392-11405.

[47] H. Kong, J. Song, J. Jang, Chem. Commun., 2010, 46, 6735-6737.

[48] A. Aijaz, J. Masa, C. Rosler, H. Antoni, R. A. Fischer, W. Schuhmann, M. Muhler, Chem. Eur. J, 2017, 23, 12125-12130.

[49] L. Lin, Q. Zhu, A. W. Xu, J. Am. Chem. Soc., 2014, 136, 11027-11033.

[50] S. J. Kim, J. Mahmood, C. Kim, G. F. Han, S. W. Kim, S. M. Jung, G. M. Zhu, J. J. De Yoreo, G. Kim, J. B. Baek, J. Am. Chem. Soc., 2018, 140, 1737-1742.

[51] Y. Li, J. H. Huang, X. Hu, L. L. Bi, P. W. Cai, J. C. Jia, G. L. Chai, S. Q. Wei, L. M. Dai, Z. H. Wen, Adv. Funct. Mater., 2018, 28, 1803330.

[52] S. Li, C. Cheng, X. Zhao, J. Schmidt, A. Thomas, Angew. Chem. Int. 
$E d ., 2018,57,1856-1862$.

[53] Y. Zhong, Z. Pan, X. Wang, J. Yang, Y. Qiu, S. Xu, Y. Lu, Q. Huang,W. Li, Adv. Sci, 2019, 1802243.

[54] T. Zhou, R. Ma, T. Zhang, Z. Li, M. Yang, Q. Liu, Y. Zhu, J. Wang, J. Colloid Interface Sci., 2019, 536, 42-52.

[55] R. Z. Zhang, C. M. Zhang, W. Chen, J. Mater. Chem. A, 2016, 4, 18723-18729.

[56] R. Ma, Y. Zhou, C. Hu, M. Yang, F. Wang, K. Yan, Q. Liu, J. Wang, Energy Storage Mater., 2018, 13, 142-150.

[57] G. X. Lin, R. G. Ma, Y. Zhou, Q. Liu, C. Hu, M. Yang, J. C. Wang, Appl.
Mater. Today, 2018, 13, 174-181.

[58] W. Yang, Y. Zhang, X. Liu, L. Chen, J. Jia, Chem. Commun., 2017, 53, 12934-12937.

[59] S. Chen, L. Zhao, J. Ma, Y. Wang, L. Dai, J. Zhang, Nano Energy, 2019, 60, 536-544.

[60] W. X. Yang, Y. L. Zhang, X. J. Liu, L. L. Chen, M. C. Liu, J. B. Jia, Carbon, 2019, 147, 83-89.

[61] J. M. Ang, Y. H. Du, B. Y. Tay, C. Y. Zhao, J. H. Kong, L. P. Stubbs, X. H. Lu, Langmuir, 2016, 32, 9265-9275.

[62] Z. K. Yang, L. Lin,A. W. Xu, Small, 2016, 12, 5710-5719.

\section{基于氮掺杂碳载铁复合物的锌空电池氧阴极催化剂}

陈 凯 ${ }^{\mathrm{a}, \mathrm{b}}$, 次素琴 ${ }^{\mathrm{a},{ }^{*}}$, 许秋华 ${ }^{\mathrm{a}}$, 蔡平伟 ${ }^{\mathrm{b}}$, 李美珍 ${ }^{\mathrm{a}}$, 向利娟 ${ }^{\mathrm{a}}$, 胡 茜 ${ }^{\mathrm{a}}$, 温珍海, ${ }^{\mathrm{b},}$

a 南昌航空大学, 江西省持久性污染物控制与资源循环利用重点实验室, 江西南昌330063

' 中国科学院福建物质结构研究所, 中科院功能纳米材料结构与组装重点实验室,

福建省纳米材料重点实验室, 福建福州 350002

摘要: 迫在眉睫的环境和能源问题推动人类探索可行、可靠和可再生的能源技术. 锌-空气电池和氢氧燃料电池等器件显 示出高能量转换效率, 但是仍有许多难题有待克服, 例如阴极侧上缓慢的氧还原反应(ORR), 以及高昂的成本极大地限制了 铂基催化剂在商业上的广泛应用. 因此, 开发高性能的廉价ORR催化剂具有重要意义. 过渡金属碳氮化合物(M-N-C, M = $\mathrm{Co}, \mathrm{Fe}$ 等)成为最有希望替代铂基催化剂的一类材料, M-N-C催化剂可以通过直接热解含有过渡金属、氮和碳物种的前驱体 合成. 然而热解时金属原子易团聚, 多孔结构不能被有效地控制, 导致相对较差的催化活性. 目前, MOF衍生的催化剂在能 源转化和储存技术中得到了广泛的关注, 其具有丰富的氮含量、高比表面积和可调的孔道结构等特点. 本文报道了一种简 便可靠可控的合成铁氮共掺杂碳十二面体纳米结构催化剂的方法, 并作为阴极电催化剂用于锌空气电池中, 测试结果证 实, 合成的铁氮共掺杂的纳米碳具有与铂基材料相当的活性和更加优异的稳定性.

表面吸附了的邻菲罗啉铁的ZIF-8在碳化过程中, 氮基团能够结合铁形成 $\mathrm{FeN}_{x}$ 结构单元, 因此可得到铁氮共掺杂的电 催化剂. 粉末X射线衍射, 扫描电镜证实ZIF-8的成功合成. 经过热解得到的催化剂中 $\mathrm{FeN}_{x}$ 或 $\mathrm{Fe}_{x}$ 衍射峰较弱, 表明样品中 铁含量较低, 存在部分无定型铁. 通过拉曼光谱分析发现, 引入的邻菲罗啉在热解过程中诱导了缺陷的形成, 所以 Fe-NCDNA- 0 的 $I_{\mathrm{D}} / I_{\mathrm{G}}$ 比值明显高于 NC. 同时 $I_{\mathrm{D}} / I_{\mathrm{G}}$ 随着铁含量的增加而减少, 这是因为铁可以诱导石墨化, 诱导效应随着铁 含量的增加而增加. 分析氮气吸附-脱附等温线得出, 引入邻菲罗啉之后, 比表面积增加; 而铁的引入因其占据了微孔结构, 导致比表面积下降. 同时电镜证实Fe-NCDNA-2具有较大的形貌扭曲, 使得该材料具有较大的比表面积.

系统的电化学研究表明, 氮掺杂有利于增强ORR活性, 在引入铁之后形成高效的活性中心会进一步提高催化性能. 因 此, Fe-NCDNA-2在碱性条件下表现出优异的ORR性能. 线性扫描伏安法曲线表明, 铁氮共掺杂的材料表现出与 Pt/C相似 的性能, 其中Fe-NCDNA-2的半波电位 $\left(E_{1 / 2}\right)$ 为 $0.863 \mathrm{~V}$, 比商业Pt/C的电位更正 $\left(E_{1 / 2}=0.841 \mathrm{~V}\right)$. 同时, Fe-NCDNA-2具有更加 优异的稳定性, 测试 $30000 \mathrm{~s}$ 后的电流保持率为 $80 \%(\mathrm{Pt} / \mathrm{C}: 64 \%)$. 在中性介质中, 合成的材料也展示了较高的ORR活性. Fe-NCDNA-2的 $E_{1 / 2}=0.715 \mathrm{~V}$, 催化 $30000 \mathrm{~s}$ 后电流保持率 $77 \%$, 均优于商业Pt/C催化剂. 组装的锌空气电池进一步验证其作 为氧还原催化剂实际应用的可行性. 相比于以 $\mathrm{Pt} / \mathrm{C}$ 为催化剂做空气阴极的电池, 以Fe-NCDNA-2组装的电池表现出更高的 开路电压, 更高的功率密度 $\left(184 \mathrm{~mW} \mathrm{~cm}^{-2}\right)$, 以及更加优异的充放电循环稳定性. 该工作也有利于启发研究人员探索类似的 氮掺杂过渡金属碳材料在各种催化上的应用.

关键词: 氧还原反应; 电催化剂; Fe-N-C活性位点; 碱性/中性介质; 锌空气电池

收稿日期: 2019-10-12. 接受日期: 2019-11-10. 出版日期: 2020-05-05.

*通讯联系人. 电子信箱: sqci@nchu.edu.cn

\#通讯联系人. 电话: (0591)6317 3534; 电子信箱: wen@fjirsm.ac.cn

基金来源：国家自然科学基金(21566025, 21875253); 江西省杰出青年学者科学基金(20162BCB23044); 江西省研究生创新专项 基金(YC2018-S362).

本文的电子版全文由Elsevier出版社在ScienceDirect上出版(http://www.sciencedirect.com/science/journal/18722067). 